\title{
KINETIC STUDY AND CHARACTERIZATION OF BORIDED AISI 4140 STEEL
}

\author{
ŠTUDIJ KINETIKE IN KARAKTERIZACIJA BORIRANEGA JEKLA \\ AISI 4140
}

\section{Mourad Keddam1, Martín Ortiz-Domínguez², Oscar Armando Gómez-Vargas ${ }^{3}$, Alberto Arenas-Flores ${ }^{4}$, Miguel Ángel Flores-Rentería ${ }^{2}$, Milton Elias-Espinosa ${ }^{5}$, Abel García-Barrientos ${ }^{6}$}

${ }^{1}$ Département de Sciences des Matériaux, Faculté de Génie Mécanique et Génie des Procédés, USTHB, B.P. No. 32, 16111 El-Alia, Bab-Ezzouar, Algiers, Algeria

${ }^{2}$ Universidad Autónoma del Estado de Hidalgo, Escuela Superior de Ciudad Sahagún-Ingeniería Mecánica, Carretera Cd. Sahagún-Otumba s/n, Zona Industrial CP. 43990 Hidalgo, México

${ }^{3}$ Instituto Tecnológico de Tlalnepantla-ITTLA. Av., Instituto Tecnológico, S/N. Col. La Comunidad, Tlalnepantla de Baz. CP. 54070 Estado de México, México

${ }^{4}$ Universidad Autónoma del Estado de Hidalgo-AACTyM, Carretera Pachuca Tulancingo Km. 4.5, Mineral de la Reforma, CP. 42184 Hidalgo, México

${ }^{5}$ Instituto Tecnológico y de Estudios Superiores de Monterrey-ITESM Campus Santa Fe, Av. Carlos Lazo No. 100, Del. Álvaro Obregón, CP. 01389 D. F., México

${ }^{6}$ Universidad Autónoma del Estado de Hidalgo-CITIS, Carretera Pachuca Tulancingo Km. 4.5, Mineral de la Reforma, CP. 42184 Hidalgo, México

keddam@yahoo.fr

Prejem rokopisa - received: 2014-02-11; sprejem za objavo - accepted for publication: 2014-10-08

doi: $10.17222 /$ mit. 2014.034

In the present study, an alternative diffusion model was proposed for analyzing the growth of $\mathrm{Fe}_{2} \mathrm{~B}$ layers formed on the AISI 4140 steel during the pack-boriding process. This model was based on solving the mass-balance equations for the $\mathrm{Fe} \mathrm{B}_{2} \mathrm{~B} / \mathrm{Fe}$ interface to evaluate boron diffusion coefficients through the $\mathrm{Fe}_{2} \mathrm{~B}$ layers in a temperature range of $1123-1273 \mathrm{~K}$. The boride incubation time for the $\mathrm{Fe}_{2} \mathrm{~B}$ phase was included in the present model. The suggested model was validated experimentally at a temperature of $1253 \mathrm{~K}$ for a treatment time of $5 \mathrm{~h}$.

Furthermore, the generated boride layers were analyzed with light microscopy, scanning electron microscopy (SEM), energy dispersive X-ray spectroscopy (EDS) and X-ray diffraction analysis (XRD). In addition, a contour diagram was also proposed as a function of treatment time and temperature. On the basis of our experimental results, the boron activation energy for the AISI 4140 steel was found to be $189.24 \mathrm{~kJ} \mathrm{~mol}^{-1}$.

Keywords: boriding, incubation time, diffusion model, growth kinetics, activation energy, adherence

V tej študiji je predlagan alternativni model difuzije za analiziranje rasti $\mathrm{Fe}_{2} \mathrm{~B}$-plasti, ki nastane na jeklu AISI 4140 pri boriranju v škatli. Ta model temelji na rešitvi enačbe ravnotežja mas na stiku $\left(\mathrm{Fe}_{2} \mathrm{~B} / \mathrm{Fe}\right)$ pri oceni koeficienta difuzije bora skozi $\mathrm{Fe}_{2} \mathrm{~B}$-sloje v temperaturnem območju 1123-1273 K. Inkubacijski čas borida za Fe,B-fazo je bil vključen v predstavljeni model. Predlagani model je bil eksperimentalno ocenjen pri temperaturi $1253 \mathrm{~K}$ in času obdelave $5 \mathrm{~h}$.

Poleg tega so bili izdelani sloji analizirani na svetlobnem mikroskopu, z vrstičnim elektronskim mikroskopom (SEM), energijsko disperzijsko rentgensko spektroskopijo (EDS) in z rentgensko difrakcijsko analizo (XRD). Dodatno je bil predlagan še konturni diagram kot funkcija časa obdelave in temperature. Na podlagi eksperimentalnih rezultatov je bilo ugotovljeno, da je aktivacijska energija bora pri jeklu AISI 4140 189,24 $\mathrm{kJ} \mathrm{mol}^{-1}$.

Ključne besede: boriranje, čas inkubacije, model difuzije, kinetika rasti, aktivacijska energija, adherenca

\section{INTRODUCTION}

Boriding is a well-known thermochemical treatment in which boron (because of its relatively small size) diffuses into the metal substrate to form hard borides. As a result of boriding, properties such as wear resistance, surface hardness and corrosion resistance are improved. ${ }^{1}$ Boriding can be carried out with boron in different states such as solid powder, paste, liquid, gas and plasma. The most frequently used method is pack boriding owing to its technical advantages. ${ }^{2}$ Generally, the commercial boriding mixture is composed of boron carbide $\left(\mathrm{B}_{4} \mathrm{C}\right)$ as a donor, $\mathrm{KBF}_{4}$ as an activator and silicon carbide $(\mathrm{SiC})$ as a diluent to control the boriding potential of the medium. The boriding treatment requires temperatures ranging from $800{ }^{\circ} \mathrm{C}$ to $1000{ }^{\circ} \mathrm{C}$. Usually the treatment time varies between $0.5 \mathrm{~h}$ and $12 \mathrm{~h}$ producing a boride layer whose thickness depends on the boriding parameters (time and temperature). The morphology of the boride layer is affected by the presence of alloying elements in the matrix. Saw-tooth-shaped layers are obtained in low-alloy steels or Armco iron whereas in high-alloy steels, the interfaces are smooth. According to the Fe-B phase diagram, ${ }^{3}$ two iron borides can be formed (FeB and $\mathrm{Fe}_{2} \mathrm{~B}$ ).

A monophase $\mathrm{Fe}_{2} \mathrm{~B}$ layer with a tooth-shaped morphology is generally suitable for industrial applications because of the difference between the specific volume and the coefficients of the thermal expansion of iron 
boride and the substrate. ${ }^{4,5}$ The boron-rich phase FeB is not preferred since $\mathrm{FeB}$ is more brittle and less tough than $\mathrm{Fe}_{2} \mathrm{~B} .{ }^{4,5}$ Furthermore, the brittleness of FeB layers causes a spalling when a high normal or tangential load is applied.

The modeling of the boriding kinetics is considered as a suitable tool to select the optimized parameters for obtaining a desired boride layer of the treated material for its practical use in the industry. In particular, many models reported in the literature were used for analyzing the kinetics of the $\mathrm{Fe}_{2} \mathrm{~B}$ layers grown on different substrates $^{6-16}$, with and without the boride incubation times.

In the current work, an alternative diffusion model, based on solving the mass-balance equation for the $\mathrm{Fe}_{2} \mathrm{~B} /$ substrate interface, was proposed to simulate the kinetics of the $\mathrm{Fe}_{2} \mathrm{~B}$ layers grown on the AISI 4140 steel. In the present model, the boride incubation time was independent of the temperature. The pack-borided AISI 4140 steel was characterized by means of the following techniques: light microscopy, scanning electron microscopy and XRD. Based on the experimental data, the boron activation energy was also evaluated when pack boriding the AISI 4140 steel in a temperature range of $1123-1273 \mathrm{~K}$.

\section{KINETIC MODEL}

The model considers the growth of the $\mathrm{Fe}_{2} \mathrm{~B}$ layer on a substrate saturated with boron atoms as illustrated in Figure 1. The $f(x, t)$ function represents the boron distribution in the iron matrix before the nucleation of the $\mathrm{Fe}_{2} \mathrm{~B}$ phase. $t_{0}^{\mathrm{Fe}_{2} \mathrm{~B}}$ corresponds to the incubation time required to form the $\mathrm{Fe}_{2} \mathrm{~B}$ phase when the matrix reaches the state of being saturated with boron atoms. $C_{\text {up }}^{\mathrm{Fe}_{2} \mathrm{~B}}$ represents the upper limit of the boron content in $\mathrm{Fe}_{2} \mathrm{~B}$ $\left(60 \cdot 10^{3} \mathrm{~mol} \mathrm{~m}^{-3}\right), C_{\text {low }}^{\mathrm{Fe}_{2} \mathrm{~B}}$ is the lower limit of the boron content in $\mathrm{Fe}_{2} \mathrm{~B}\left(59.8 \cdot 10^{3} \mathrm{~mol} \mathrm{~m}^{-3}\right)$ and the point $x(t=t)$ $=v$ represents the $\mathrm{Fe}_{2} \mathrm{~B}$ layer thickness. ${ }^{17,18}$

The term $C_{\text {ads }}^{\mathrm{B}}$ represents the effective adsorbed boron concentration during the boriding process. ${ }^{19}$ In Figure 1, $a_{1}=C_{\text {up }}^{\mathrm{Fe}_{2} \mathrm{~B}}-C_{\text {low }}^{\mathrm{Fe}_{2} \mathrm{~B}}$ defines the homogeneity range of the $\mathrm{Fe}_{2} \mathrm{~B}$ layer, $a_{2}=C_{\text {low }}^{\mathrm{Fe}_{2} \mathrm{~B}}-C_{0}$ is the miscibility gap ${ }^{15,16}$ and $C_{0}$ is the boron solubility in the matrix considered as zero. ${ }^{3}$ The following assumptions are considered for the diffusion model:

- The growth kinetics is controlled by the boron diffusion in the $\mathrm{Fe}_{2} \mathrm{~B}$ layer.

- The $\mathrm{Fe}_{2} \mathrm{~B}$ iron boride nucleates after a specific incubation time.

- The boride layer grows because of the boron diffusion perpendicular to the specimen surface.

- Boron concentrations remain constant in the boride layer during the treatment.

- The influence of the alloying elements on the growth kinetics of the layer is not taken into account.
- The boride layer is thin compared to the sample thickness.

- A uniform temperature is assumed throughout the sample.

- A planar morphology is assumed for the phase interface.

The initial and boundary conditions for the diffusion problem are represented as:

$$
t=0, x>0 \text {, with: } C_{\mathrm{Fe}_{2} \mathrm{~B}}[x(t), t=0]=C_{0} \approx 0
$$

Boundary conditions:

$$
C_{\mathrm{Fe}_{2} \mathrm{~B}}\left[x\left(t=t_{0}^{\mathrm{Fe}_{2} \mathrm{~B}}\right)=v_{0}, t=t_{0}^{\mathrm{Fe}_{2} \mathrm{~B}}\right]=C_{\text {up }}^{\mathrm{Fe}_{2} \mathrm{~B}}
$$

(the upper boron concentration is kept constant)

for $C_{\text {ads }}^{\mathrm{B}}>60 \cdot 10^{3} \mathrm{~mol} \mathrm{~m}^{-3}$ :

$C_{\mathrm{Fe}_{2} \mathrm{~B}}[x(t=t)=v, t=t]=C_{\text {low }}^{\mathrm{Fe}_{2} \mathrm{~B}}$

(the upper boron concentration is kept constant) for $C_{\text {ads }}^{\mathrm{B}}<59.8 \cdot 10^{3} \mathrm{~mol} \mathrm{~m}^{-3}$

$v_{0}$ is a thin layer with a thickness of $\approx 5 \mathrm{~nm}$ that formed during the nucleation stage, ${ }^{20}$ thus $v_{0}(\approx 0)$ is used when compared to the thickness of the $\mathrm{Fe}_{2} \mathrm{~B}$ layer $(v)$. The mass-balance equation at the $\mathrm{Fe}_{2} \mathrm{~B}$ /substrate interface can be formulated with Equation (4) as follows:

$\left(\frac{C_{\text {up }}^{\mathrm{Fe}_{2} \mathrm{~B}}+C_{\text {low }}^{\mathrm{Fe}_{2} \mathrm{~B}}-2 C_{0}}{2}\right)(A \cdot \mathrm{d} v)=$

$=J_{\mathrm{Fe}_{2} \mathrm{~B}}(x=v, t=t)(A \cdot \mathrm{d} t)-J_{\mathrm{Fe}}(x=v+\mathrm{d} v, t=t)(A \cdot \mathrm{d} t)$

where $A(=1.1)$ is defined as the unit area and $C_{0}$ represents the boron concentration in the matrix. The fluxes $J_{\mathrm{Fe}_{2} \mathrm{~B}}$ and $J_{\mathrm{Fe}}$ are obtained from the Fick's first law as:

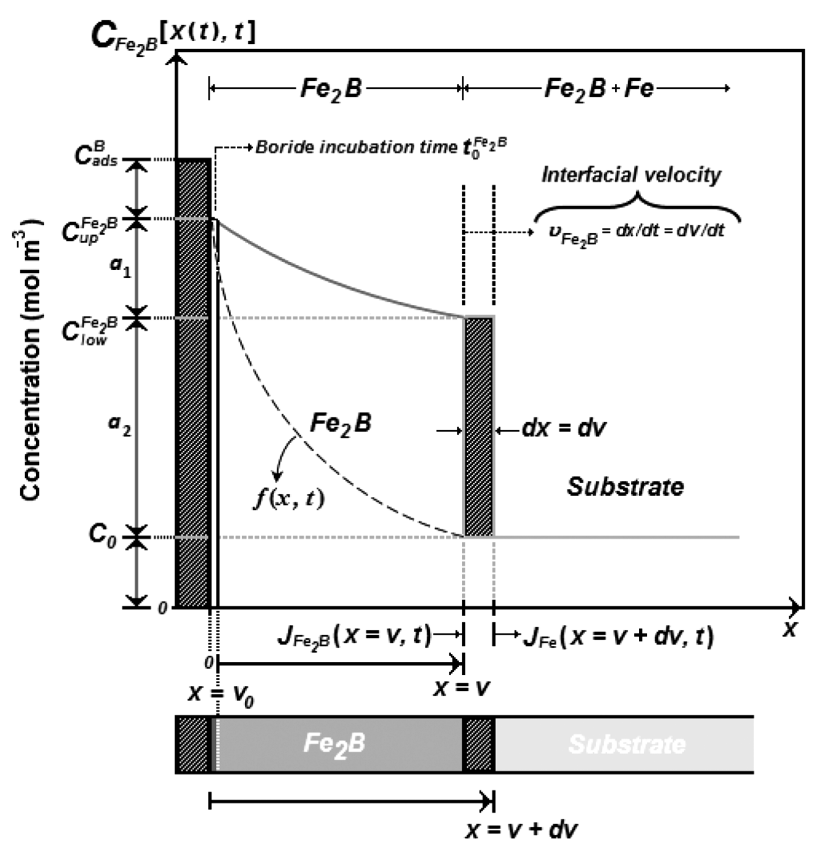

Figure 1: Schematic boron-concentration profile through the $\mathrm{Fe}_{2} \mathrm{~B}$ layer

Slika 1: Shematski prikaz profila koncentracije bora skozi $\mathrm{Fe}_{2} \mathrm{~B}$-plast 


$$
\begin{aligned}
& \left.J_{\mathrm{Fe}_{2} \mathrm{~B}}[x(t=t)=v, t=t)\right]= \\
& =-\left\{\frac{\left.D_{\mathrm{Fe}_{2} \mathrm{~B}} \partial C_{\mathrm{Fe}_{2} \mathrm{~B}}[x(t=t)=v, t=t)\right]}{\partial x}\right\}_{x=v}
\end{aligned}
$$

and:

$\left.J_{\mathrm{Fe}}[x(t=t)=v+\mathrm{d} v, t=t)\right]=$

$=-\left\{\frac{\left.D_{\mathrm{Fe}} \partial C_{\mathrm{Fe}}[x(t=t)=v+\mathrm{d} v, t=t)\right]}{\partial x}\right\}_{x=v+\mathrm{d} v}$

The term $J_{\mathrm{Fe}}$ is zero since the boron solubility in the matrix is very low $\left(\approx 0 \mathrm{~mol} \mathrm{~m}^{-3}\right){ }^{3}$

Thus, Equation (4) can be written as:

$$
\begin{aligned}
& \left.\left(\frac{C_{\mathrm{up}}^{\mathrm{Fe}_{2} \mathrm{~B}}+C_{\mathrm{low}}^{\mathrm{Fe}_{2} \mathrm{~B}}-2 C_{0}}{2}\right) \frac{\mathrm{d} x(t)}{\mathrm{d} t}\right|_{x(t)=v}= \\
& =-\left.D_{\mathrm{Fe}_{2} \mathrm{~B}} \frac{\partial C_{\mathrm{Fe}_{2} \mathrm{~B}}[x(t=t), t=t]}{\partial x}\right|_{x(t)=v}
\end{aligned}
$$

The Fick's second law of diffusion relating to the change in the boron concentration through the $\mathrm{Fe}_{2} \mathrm{~B}$ layer with the time $t$ and the distance $x(t)$ is given with Equation (8) :

$\frac{\partial C_{\mathrm{Fe}_{2} \mathrm{~B}}[x(t), t]}{\partial t}=D_{\mathrm{Fe}_{2} \mathrm{~B}} \frac{\partial^{2} C_{\mathrm{Fe}_{2} \mathrm{~B}}[x(t), t]}{\partial x^{2}}$

When applying the boundary conditions proposed in Equations (2) and (3), the solution of Equation (8) takes the following form:

$C_{\mathrm{Fe}_{2} \mathrm{~B}}[x(t), t]=C_{\text {up }}^{\mathrm{Fe}_{2} \mathrm{~B}}+\frac{C_{\mathrm{low}_{2}}^{\mathrm{Fe}_{2} \mathrm{~B}}-C_{\mathrm{up}_{2} \mathrm{~B}}^{\mathrm{Fe}_{2} \mathrm{~B}}}{\operatorname{erf}\left(\frac{v}{2 \sqrt{D_{\mathrm{Fe}_{2} \mathrm{~B}} t}}\right)} \cdot \operatorname{erf}\left(\frac{x}{2 \sqrt{D_{\mathrm{Fe}_{2} \mathrm{~B}} t}}\right)(9)$

By substituting the derivative of Equation (9) with respect to the distance $x(t)$ in Equation (7), Equation (10) is obtained:

$$
\begin{aligned}
& \left(\frac{C_{\text {up }}^{\mathrm{Fe}_{2} \mathrm{~B}}+C_{\text {low }}^{\mathrm{Fe}_{2} \mathrm{~B}}-2 C_{0}}{2}\right) \frac{\mathrm{d} v}{\mathrm{~d} t}= \\
& =\sqrt{\frac{D_{\mathrm{Fe}_{2} \mathrm{~B}}}{\pi t}} \cdot \frac{\left(C_{\text {up }}^{\mathrm{Fe}_{2} \mathrm{~B}}-C_{\mathrm{low}_{2}}^{\mathrm{Fe}_{2} \mathrm{~B}}\right)}{\operatorname{erf}\left(\frac{v}{2 \sqrt{D_{\mathrm{Fe}_{2} \mathrm{~B}} t}}\right)} \cdot \exp \left(-\frac{v^{2}}{4 D_{\mathrm{Fe}_{2} \mathrm{~B}} t}\right)
\end{aligned}
$$

for $0 \leq x \leq v$.

Substituting the expression of the parabolic growth law $\left(v=2 \varepsilon \sqrt{D_{\mathrm{Fe}_{2} \mathrm{~B}} t}\right)$ in Equation (10), Equation (11) is deduced:

$$
\begin{aligned}
& \left(\frac{C_{\text {up }}^{\mathrm{Fe}_{2} \mathrm{~B}}+C_{\text {low }}^{\mathrm{Fe}_{2} \mathrm{~B}}-2 C_{0}}{2}\right) \varepsilon= \\
& =\sqrt{\frac{1}{\pi}}\left(\frac{C_{\text {up }_{2} \mathrm{~B}}^{\mathrm{Fe}_{2}}-C_{\text {low }}^{\mathrm{Fe}_{2} \mathrm{~B}}}{\operatorname{erf}(\varepsilon)}\right) \exp \left(-\varepsilon^{2}\right)
\end{aligned}
$$

The normalized growth parameter $(\varepsilon)$ for the $\mathrm{Fe}_{2} \mathrm{~B} /$ substrate interface can be estimated numerically using the Newton-Raphson method. It is assumed that expressions $C_{\text {up }}^{\mathrm{Fe}_{2} \mathrm{~B}}, C_{\text {low }}^{\mathrm{Fe}_{2} \mathrm{~B}}$ and $C_{0}$ do not depend significantly on the temperature (in the considered temperature range). ${ }^{18}$

A schematic representation of the square of the layer thickness against the linear time $\left(v^{2}=4 \varepsilon^{2} D_{\mathrm{Fe}_{2} \mathrm{~B}} t=\right.$ $\left.4 \varepsilon^{2} D_{\mathrm{Fe}_{2} \mathrm{~B}}\left[t_{\mathrm{v}}+t_{0}^{\mathrm{Fe}_{2} \mathrm{~B}}(T)\right]\right)$ is depicted in Figure 2. $t_{\mathrm{v}}(=t-$ $t_{0}^{\mathrm{Fe}_{2} \mathrm{~B}}$ ) is the effective growth time of the $\mathrm{Fe}_{2} \mathrm{~B}$ layer and $t$ is the treatment time.

\section{EXPERIMENTAL PROCEDURE}

\subsection{Boriding process}

The AISI 4140 steel was used in this experimental study. It had a nominal chemical composition of $0.38-0.43 \% \mathrm{C}, 0.75-1.00 \% \mathrm{Mn}, 0.80-1.10 \% \mathrm{Cr}$, $0.15-0.30 \% \mathrm{Si}, 0.040 \% \mathrm{~S}$, and $0.035 \%$ P. Samples had a cubic shape with dimensions of $10 \mathrm{~mm} \times 10 \mathrm{~mm} \times 10$ $\mathrm{mm}$. Prior to the boriding process, the specimens were polished, ultrasonically cleaned in an alcohol solution and deionized water for $15 \mathrm{~min}$ at room temperature, dried and stored under clean-room conditions. The samples were packed along with a Durborid fresh powder mixture in a closed cylindrical case (AISI 304L). The used powder mixture had an average size of $30 \mu \mathrm{m}$. The powder-pack boriding process was carried out in a conventional furnace under a pure argon atmosphere in the temperature range of $1123-1273 \mathrm{~K}$. Four treatment times $((2,4,6$ and 8$) \mathrm{h})$ were selected for each temperature. After the completion of the boriding treatment, the container was removed from the furnace and slowly cooled to room temperature.

\subsection{Microscopical observations of boride layers}

The borided samples were cross-sectioned for metallographic examinations using a LECO VC-50 precision cutting machine. The cross-sectional morphology of the boride layers was observed with an Olympus GX51 light microscope in a clear field. Figure 3 shows cross-sectional views of light images of the $\mathrm{Fe}_{2} \mathrm{~B}$ layers of the AISI 4140 steel formed at a temperature of 1223 $\mathrm{K}$ over different process durations.

The resultant microstructures of the $\mathrm{Fe}_{2} \mathrm{~B}$ layers appear to be very dense and homogenous, exhibiting saw-tooth morphologies. Since the growth of a saw-tooth boride layer is a controlled diffusion process with a highly anisotropic nature, higher temperatures and/or 


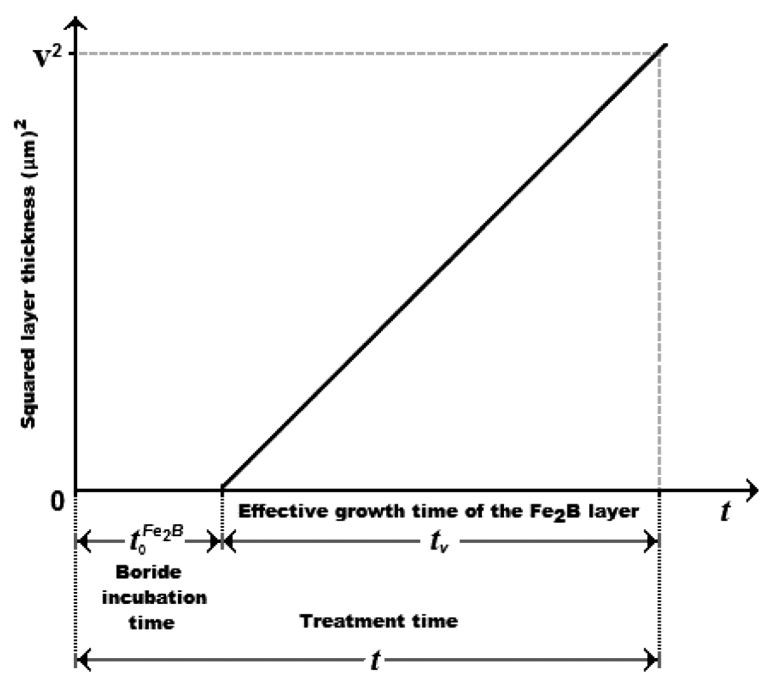

Figure 2: Schematic representation of the square of the layer thickness against the treatment time

Slika 2: Shematski prikaz kvadrata debeline plasti, odvisno od časa obdelave

longer times stimulated the $\mathrm{Fe}_{2} \mathrm{~B}$ crystals to make contact with the adjacent crystals and forced them to retain an acicular shape. ${ }^{21}$ It is seen that the thickness of the $\mathrm{Fe}_{2} \mathrm{~B}$ layer increased with an increase in the boriding time (Figure 3) because the boriding kinetics is influenced by the treatment time. For the kinetic study, the boride-layer thickness was automatically measured with the aid of the MSQ PLUS software. To ensure the reproducibility of the measured layer thicknesses, fifty measurements were collected in different sections of the samples of the borided AISI 4140 steel to estimate the $\mathrm{Fe}_{2} \mathrm{~B}$ layer thickness, defined as the average value of the long boride teeth. ${ }^{22-24}$ All the thickness measurements were taken from a fixed reference on the surface of the borided AISI 4140 steel, as illustrated in Figure 4.
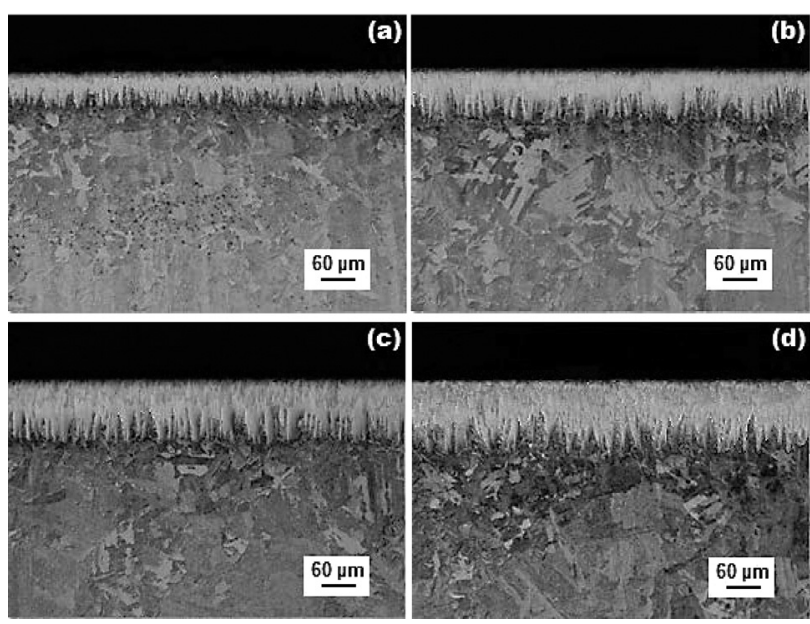

Figure 3: Light micrographs of the boride layers formed on the surface of AISI 4140 steel treated at $1223 \mathrm{~K}$ for variable times: a) $2 \mathrm{~h}$, b) $4 \mathrm{~h}$, c) $6 \mathrm{~h}$ and d) $8 \mathrm{~h}$

Slika 3: Svetlobni posnetki boriranih plasti, nastalih na površini jekla AISI 4140 pri temperaturi $1223 \mathrm{~K}$ in različnem trajanju: a) $2 \mathrm{~h}$, b) $4 \mathrm{~h}$, c) $6 \mathrm{~h}$ in d) $8 \mathrm{~h}$
The phases of the boride layers were investigated with X-ray diffraction (XRD) equipment (Equinox 2000) using Co- $K_{\alpha}$ radiation with a wavelength of $0.179 \mathrm{~nm}$. The elemental distribution within the cross-section of a boride layer was determined with electron dispersive spectroscopy (EDS) equipment (JEOL JSM 6300 LV), from the surface.

\section{RESULTS AND DISCUSSIONS}

\subsection{SEM observations and EDS analyses}

A cross-sectional view of the SEM micrograph of the AISI 4140 steel borided at $1273 \mathrm{~K}$ for $6 \mathrm{~h}$ is shown in Figure 5a. The boride layer grown on the substrate has a saw-tooth morphology. The needles of $\mathrm{Fe}_{2} \mathrm{~B}$, with different lengths, are visible on the SEM micrograph, penetrating into the substrate. This typical morphology is responsible for a good adhesion to the substrate. EDS results obtained with SEM are shown in Figures $\mathbf{5 b}$ and 5c. These results indicate the presence of two elements at the surface: Fe and $\mathrm{Cr}$ (Figure 5a). The results also show the possible dissolution of chromium in $\mathrm{Fe}_{2} \mathrm{~B}$. In fact, the atomic radius of $\mathrm{Cr}(=0.166 \mathrm{~nm})$ is about the same and larger than that of $\mathrm{Fe}(=0.155 \mathrm{~nm})$, and it can then be expected that $\mathrm{Cr}$ dissolved in the Fe sublattice of $\mathrm{Fe}_{2} \mathrm{~B}$. The obtained result in Figure 5c indicates the presence of the following elements: $\mathrm{Fe}, \mathrm{C}, \mathrm{Cr}, \mathrm{Si}$ and $\mathrm{Mn}$ in the vicinity of the $\mathrm{Fe}_{2} \mathrm{~B}$ /substrate interface. It is seen that two elements (carbon and silicon) are not dissolved in $\mathrm{Fe}_{2} \mathrm{~B}$, being displaced towards the substrate. Silicon and boron may form complex phases such as $\mathrm{FeSi}_{0.4} \mathrm{~B}_{0.6}, \mathrm{FeSiB}$ and boron cementite $\left(\mathrm{Fe}_{3} \mathrm{~B}_{0.67} \mathrm{C}_{0.33}\right){ }^{25}$

\subsection{X-ray diffraction analysis}

Figure 6 displays the XRD pattern recorded on the surface of the AISI 4140 steel borided at a temperature of $1273 \mathrm{~K}$ for a treatment time of $8 \mathrm{~h}$. The diffraction peaks relative to the $\mathrm{Fe}_{2} \mathrm{~B}$ phase are easily identified. Peaks with very small intensities are also observed for

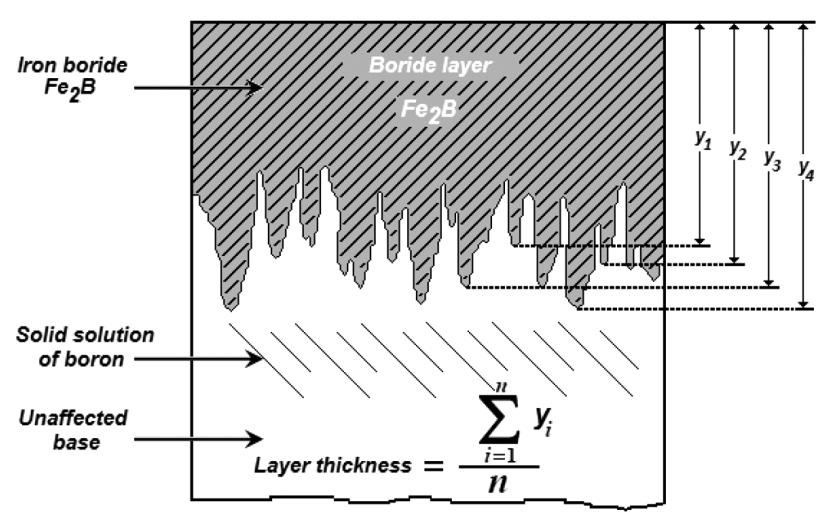

Figure 4: Schematic diagram illustrating the procedure for estimating the boride-layer thickness on the AISI 4140 steel

Slika 4: Shematski diagram, ki prikazuje postopek za ugotavljanje debeline borirane plasti na jeklu AISI 4140 
the $\mathrm{FeB}$ phase but the $\mathrm{Fe}_{2} \mathrm{~B}$ phase is dominant with high-peak intensities. The $\mathrm{CrB}$ phase is also visible in the XRD pattern recorded at the surface of the borided AISI 4140 steel. In the experimental study about the boriding of the AISI 4140 steel in molten borax, boric acid and a ferro-silicon bath performed by Sen et al. ${ }^{26}$, the XRD study showed the presence of $\mathrm{FeB}, \mathrm{Fe}_{2} \mathrm{~B}$ and $\mathrm{CrB}$ at the surface of a sample borided at $1223 \mathrm{~K}$ for $6 \mathrm{~h}$. In addition, Ulutan et al. ${ }^{27}$ also identified, with an XRD analysis, the same phases at the surface of the AISI 4140 steel (at $1000{ }^{\circ} \mathrm{C}$ for $6 \mathrm{~h}$ ) after the powder-pack boriding.

Crystals of the $\mathrm{Fe}_{2} \mathrm{~B}$ type orientate themselves with the $z$-axis perpendicular to the surface. Consequently, the peaks of the $\mathrm{Fe}_{2} \mathrm{~B}$ phase belonging to the crystallographic planes and having a deviation from zero of the $l$ index, showed increased intensities in the X-ray diffraction spectra. ${ }^{28}$
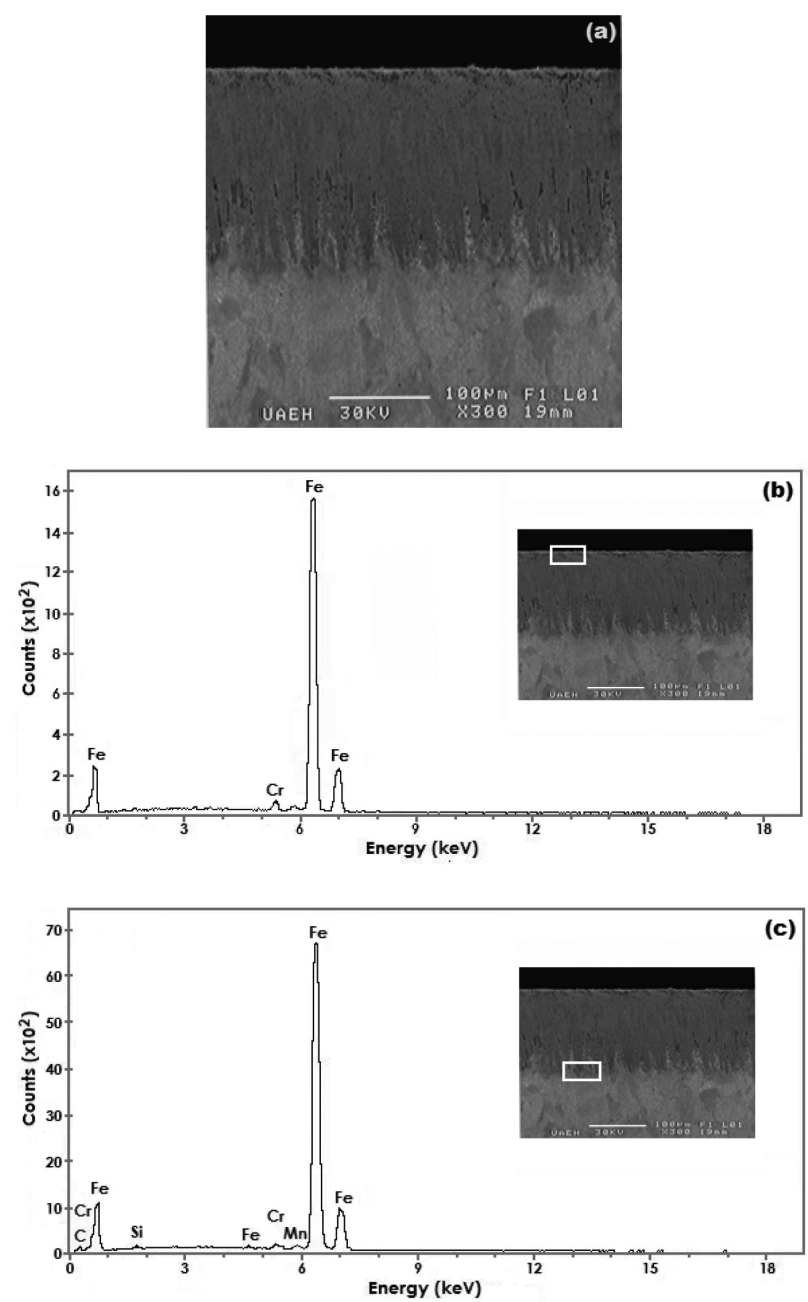

Figure 5: a) SEM micrograph of the cross-section of the AISI 4140 steel borided at $1273 \mathrm{~K}$ for $6 \mathrm{~h}, \mathrm{~b}$ ) EDS spectrum of the surface of a borided sample and c) EDS spectrum of the interface of a borided sample

Slika 5: a) SEM-posnetek prereza boriranega jekla AISI 4140 po $6 \mathrm{~h}$ na $1273 \mathrm{~K}$, b) EDS-spekter boriranega vzorca na površini in c) EDS-spekter boriranega vzorca na stiku z osnovo
The growth of boride layers is a controlled diffusion process with a highly anisotropic nature. In the case of the $\mathrm{Fe}_{2} \mathrm{~B}$ phase, the [001] crystallographic direction is the easiest path for the boron diffusion in $\mathrm{Fe}_{2} \mathrm{~B}$ because of the tendency of the boride crystals to grow along the direction of minimum resistance, perpendicular to the external surface. As the metal surface is covered, an increasing number of the $\mathrm{Fe}_{2} \mathrm{~B}$ crystals come in contact with the adjacent crystals, being forced to grow inside the metal and retaining the acicular shape. ${ }^{21}$ In the powder-pack boriding, the active boron is supplied by the powder mixture. To form a $\mathrm{Fe}_{2} \mathrm{~B}$ phase on any borided steel, a low boron potential is required as reported in the reference works ${ }^{4,29}$, while a high amount of active boron in a powder mixture gives rise to a bilayer configuration consisting of $\mathrm{FeB}$ and $\mathrm{Fe}_{2} \mathrm{~B}$.

\subsection{Estimation of the boron activation energy}

The growth kinetics of the $\mathrm{Fe}_{2} \mathrm{~B}$ layers formed on the AISI 4140 steel was used to estimate the boron diffusion coefficient through the $\mathrm{Fe}_{2} \mathrm{~B}$ layers by applying the suggested diffusion model. The $\varepsilon$ parameter is then determined by solving the mass-balance equation for the $\mathrm{Fe}_{2} \mathrm{~B} /$ substrate interface (Equation (11)) using the Newton-Raphson method. Table 1 lists the estimated value of boron diffusion coefficient in $\mathrm{Fe}_{2} \mathrm{~B}$ at each temperature along with the squared value of normalized growth parameter $\varepsilon$ determined from Equation (11). Figure 7 depicts the time dependence of the squared value of the $\mathrm{Fe}_{2} \mathrm{~B}$ layer thickness. The slopes of the straight lines in this figure provide the values of the growth constants $\left(=4 \varepsilon^{2} D_{\mathrm{Fe}_{2} \mathrm{~B}}\right)$ for each boriding temperature. The values of the boron diffusion coefficients in the $\mathrm{Fe}_{2} \mathrm{~B}$ layers can be determined by knowing the value of the $\varepsilon$ parameter. The boride incubation times for $\mathrm{Fe}_{2} \mathrm{~B}$ can also be deduced from the straight lines displayed in Figure 7 by extrapolating them to the boride-layer thickness of zero.

To estimate the boron activation energy for the AISI 4140 steel, it is necessary to plot the natural logarithm of

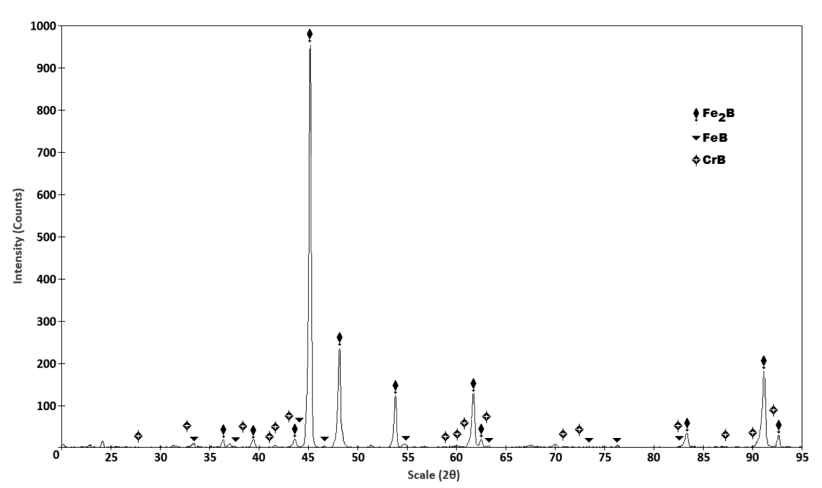

Figure 6: XRD pattern obtained at the surface of the borided AISI 4140 steel treated at $1273 \mathrm{~K}$ for $8 \mathrm{~h}$

Slika 6: Rentgenogram, dobljen na površini boriranega jekla AISI 4140 po 8 h na $1273 \mathrm{~K}$ 


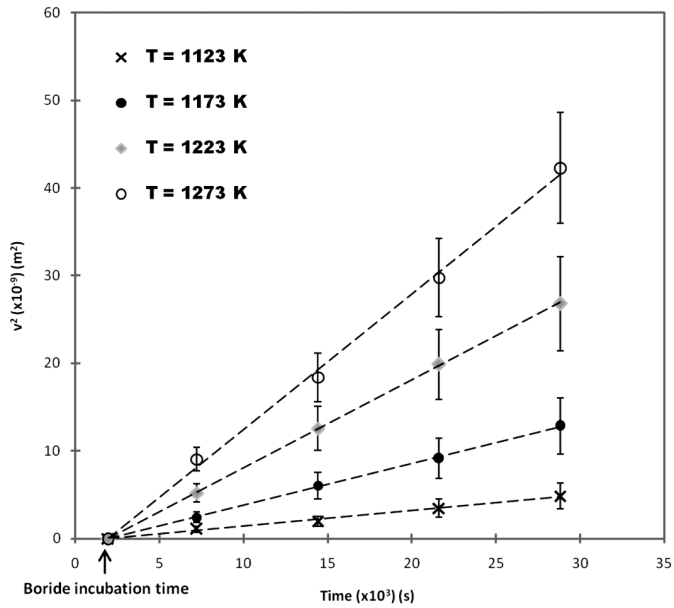

Figure 7: Evolution of the squared value of $\mathrm{Fe}_{2} \mathrm{~B}$ layer thickness as a function of boriding time

Slika 7: Razvoj vrednosti kvadrata debeline plasti $\mathrm{Fe}_{2} \mathrm{~B}$ v odvisnosti od časa boriranja

Table 1: Squared value of normalized growth parameter and boron diffusion coefficients for $\mathrm{Fe}_{2} \mathrm{~B}$ as a function of boriding temperature Tabela 1: Kvadratna vrednost normaliziranih parametrov rasti in koeficientov difuzije bora $\mathrm{v} \mathrm{Fe}_{2} \mathrm{~B} v$ odvisnosti od temperature boriranja

\begin{tabular}{|c|c|c|c|}
\hline $\begin{array}{c}\text { Temperature } \\
(\mathrm{K})\end{array}$ & Type of layer & $\begin{array}{c}\varepsilon^{2} \\
(\text { Dimen- } \\
\text { sionless })\end{array}$ & $\begin{array}{c}4 \varepsilon^{2} D_{\mathrm{Fe}_{2} \mathrm{~B}} \\
\left(\mu \mathrm{m}^{2} \mathrm{~s}^{-1}\right)\end{array}$ \\
\hline 1123 & \multirow{2}{*}{$\mathrm{Fe}_{2} \mathrm{~B}$} & \multirow{2}{*}{$1.7 \times 10^{-3}$} & $1.51 \times 10^{-1}$ \\
\cline { 1 - 1 } & & & $9.11 \times 10^{-1}$ \\
\hline 1223 & & $9.12 \times 10^{-1}$ \\
\hline 1273 & & & $16.3 \times 10^{-1}$ \\
\hline
\end{tabular}

the boron diffusion coefficient for $\mathrm{Fe}_{2} \mathrm{~B}$ versus the reciprocal temperature following the Arrhenius equation (Figure 8). A linear fitting was assumed to obtain the temperature dependence of the boron diffusion coefficient for $\mathrm{Fe}_{2} \mathrm{~B}$ with a correlation factor of 0.9935 :

$D_{\mathrm{Fe}_{2} \mathrm{~B}}=1.51 \times 10^{-2} \exp \left(\frac{-189.24 \mathrm{~kJ} \mathrm{~mol}^{-1}}{R T}\right)$

where $R=8.3144621 \mathrm{~J} \mathrm{~mol}^{-1} \mathrm{~K}^{-1}$ and $T$ is the absolute temperature in Kelvin.

Table 2 shows a comparison of the boron activation energies for some borided steels. ${ }^{26,30-32}$ The found value of the boron activation energy $\left(=189.24 \mathrm{~kJ} \mathrm{~mol}^{-1}\right)$ for the AISI 4140 steel is slightly different from the value reported in ${ }^{26}$ due to the boriding conditions (using the liquid-boriding method).

\subsection{Validation of the diffusion model}

The present model was validated by comparing the experimental value of the $\mathrm{Fe}_{2} \mathrm{~B}$ layer thickness with the predicted result at a temperature of $1253 \mathrm{~K}$ for a treatment time of $5 \mathrm{~h}$ using Equation (13):

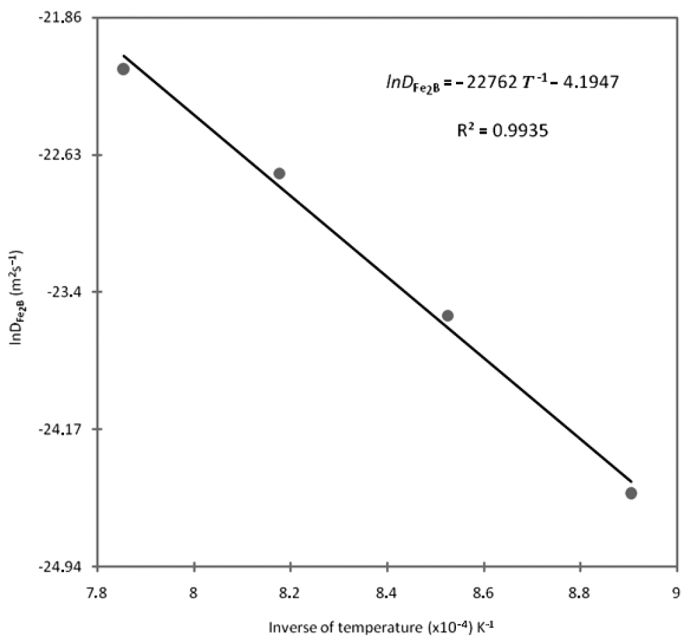

Figure 8: Temperature dependence of the boron diffusion coefficient for $\mathrm{Fe}_{2} \mathrm{~B}$

Slika 8: Temperaturna odvisnost koeficienta difuzije $v \mathrm{Fe}_{2} \mathrm{~B}$

Table 2: Comparison of the boron activation energies for some borided steels

Tabela 2: Primerjava aktivacijskih energij bora pri nekaterih boriranih jeklih

\begin{tabular}{|c|c|c|}
\hline Material & $\begin{array}{c}\text { Boron activation } \\
\text { energy }\left(\mathrm{kJ} \mathrm{mol}^{-1}\right)\end{array}$ & References \\
\hline AISI 5140 & 223 & 30 \\
AISI 4340 & 324 & 30 \\
AISI 1040 & 118.8 & 31 \\
AISI 51100 & 106.0 & 32 \\
AISI 4140 & 215 & 26 \\
AISI 4140 & 189.24 & Present study \\
\hline
\end{tabular}

$v=\frac{4}{\sqrt{\pi}}\left(\frac{C_{\text {up }}^{\mathrm{Fe}_{2} \mathrm{~B}}-C_{\text {low }}^{\mathrm{Fe}_{2} \mathrm{~B}}}{C_{\text {up }}^{\mathrm{Fe}_{2} \mathrm{~B}}+C_{\text {low }}^{\mathrm{Fe}_{2} \mathrm{~B}}}\right) \cdot \frac{\exp \left(-\varepsilon^{2}\right)}{\operatorname{erf}(\varepsilon)} \sqrt{D_{\mathrm{Fe}_{2} \mathrm{~B}} t}$

Figure 9 shows the optical image of the boride layer formed at $1253 \mathrm{~K}$ after $5 \mathrm{~h}$ of treatment.

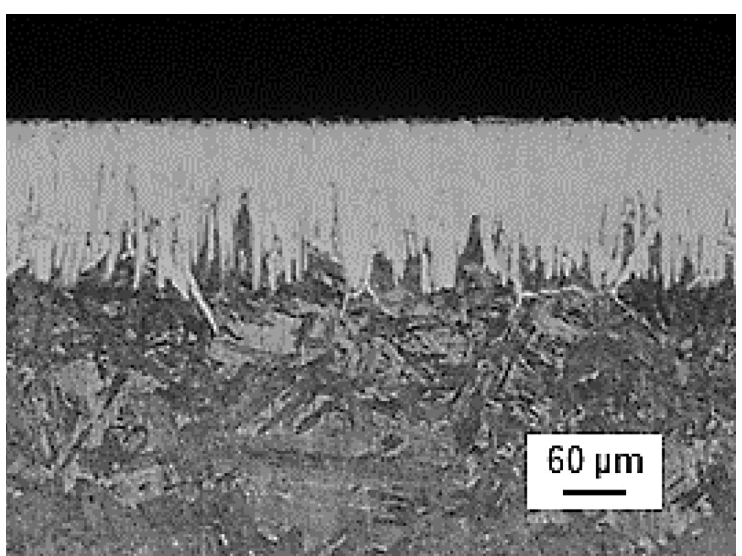

Figure 9: Light micrograph of the cross-section of the borided AISI 4140 treated at $1253 \mathrm{~K}$ for $5 \mathrm{~h}$

Slika 9: Svetlobni posnetek prereza boriranega jekla AISI 4140 po $5 \mathrm{~h}$ na $1253 \mathrm{~K}$ 
Table 3 gives a comparison between the experimental value of the $\mathrm{Fe}_{2} \mathrm{~B}$ layer thickness and the one predicted on the basis of Equation (13). A good agreement was obtained between the experimental value of the $\mathrm{Fe}_{2} \mathrm{~B}$ layer thickness and the predicted one for the AISI 4140 steel borided at $1253 \mathrm{~K}$ for $5 \mathrm{~h}$.

Table 3: Predicted and estimated values of the $\mathrm{Fe}_{2} \mathrm{~B}$ layer thickness obtained at $1253 \mathrm{~K}$ for a treatment time of $5 \mathrm{~h}$

Tabela 3: Predvidene in dobljene vrednosti za debelino plasti $\mathrm{Fe}_{2} \mathrm{~B}$ po $5 \mathrm{~h}$ na $1253 \mathrm{~K}$

\begin{tabular}{|c|c|c|c|}
\hline $\begin{array}{c}\text { Temperature } \\
(\mathrm{K})\end{array}$ & $\begin{array}{c}\text { Type of } \\
\text { layer }\end{array}$ & $\begin{array}{c}\text { Boride-layer } \\
\text { thickness }(\mu \mathrm{m}) \\
\text { estimated by } \\
\text { Eq. }(13)\end{array}$ & $\begin{array}{c}\text { Experimental } \\
\text { boride-layer } \\
\text { thickness }(\mu \mathrm{m})\end{array}$ \\
\hline 1253 & $\mathrm{Fe}_{2} \mathrm{~B}$ & 154.48 & $158.12 \pm 10.43$ \\
\hline
\end{tabular}

\subsection{Future exploitation of the simulation results}

This kinetic approach can be used as a tool to determine the $\mathrm{Fe}_{2} \mathrm{~B}$ layer thickness as a function of boriding parameters (time and temperature) for the AISI 4140 steel. Equation (13) predicts the $\mathrm{Fe}_{2} \mathrm{~B}$ layer thickness for any temperature and boriding time. An iso-thickness diagram was plotted as a function of the temperature and exposure time as shown in Figure 10.

The results of Figure $\mathbf{1 0}$ can serve as a powerful tool to select the optimum value of the $\mathrm{Fe}_{2} \mathrm{~B}$ layer thickness in relation with the potential applications of the borided AISI 4140 steel at industrial scale.

As a rule, thin layers (e.g., 15-20 $\mu \mathrm{m}$ ) are used to protect against adhesive wear (in the cases of chiplessshaping and metal-stamping dies and tools), whereas thick layers are recommended for combating abrasive wear (extrusion tooling for plastics with abrasive fillers and pressing tools for the ceramic industry). In the case of low-carbon steels and low-alloy steels, the optimum boride-layer thicknesses range from $50 \mu \mathrm{m}$ to $250 \mu \mathrm{m}$. Finally, this model can be extended to predict the growth kinetics of a bilayer configuration $\left(\mathrm{FeB}+\mathrm{Fe}_{2} \mathrm{~B}\right)$ grown on any boride steel.

\section{CONCLUSIONS}

The AISI 4140 steel was pack borided in the temperature range of $1123-1273 \mathrm{~K}$ over the treatment times varying from $2 \mathrm{~h}$ to $8 \mathrm{~h}$. The $\mathrm{Fe}_{2} \mathrm{~B}$ layers were formed on the AISI 4140 steel substrate. A mathematical model was suggested to estimate the boron diffusion coefficients for the $\mathrm{Fe}_{2} \mathrm{~B}$ layers. The boron activation energy for the AISI 4140 steel was found to be $189.24 \mathrm{~kJ} \mathrm{~mol}^{-1}$. This value was compared with the data reported in the literature.

The validity of the diffusion model was examined by comparing the experimental value of the $\mathrm{Fe}_{2} \mathrm{~B}$ layer thickness obtained at $1253 \mathrm{~K}$ after $5 \mathrm{~h}$ of treatment with that predicted by the model.

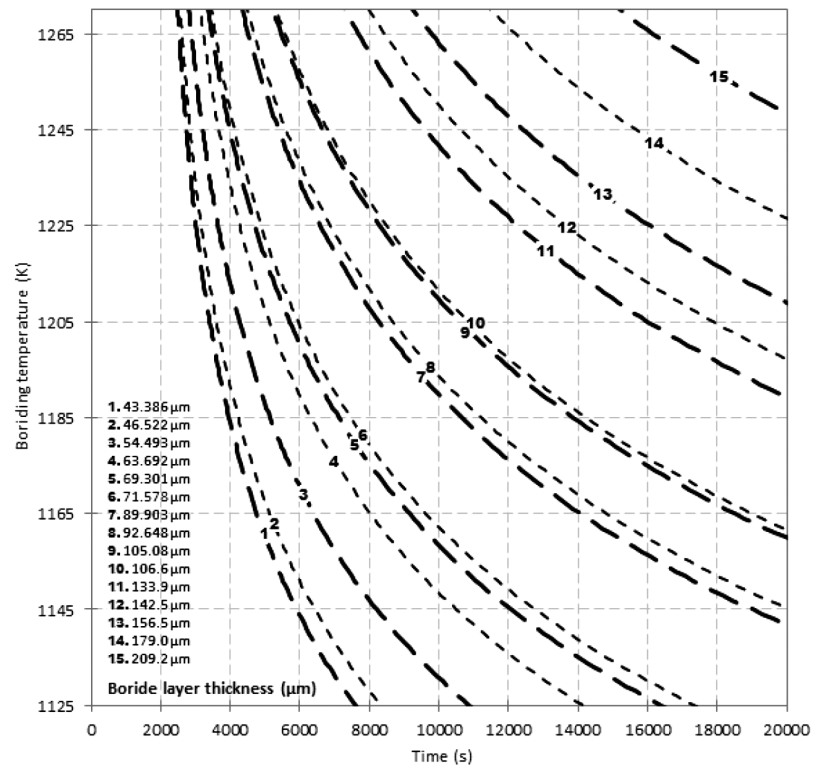

Figure 10: Iso-thickness diagram describing the evolution of $\mathrm{Fe}_{2} \mathrm{~B}$ layer as a function of boriding parameters

Slika 10: Diagram enakih debelin, ki opisuje nastanek $\mathrm{Fe}_{2} \mathrm{~B}$-plasti v odvisnosti od parametrov boriranja

Finally, an iso-thickness diagram was proposed to be used as a tool to select the optimum boride layer thickness in relation with the industrial use of this steel grade.

\section{NOMENCLATURE}

$v$ is the boride-layer thickness (m)

$t_{\mathrm{v}}$ is the effective growth time of the $\mathrm{Fe}_{2} \mathrm{~B}$ layer (s)

$t$ is the treatment time (s)

$t_{0}{ }^{\mathrm{Fe}_{2} \mathrm{~B}}$ is the boride incubation time (s)

$C_{\text {up }}^{\mathrm{Fe}_{2} \mathrm{~B}}$ represents the upper limit of the boron content in

$\mathrm{Fe}_{2} \mathrm{~B}\left(60 \cdot 10^{3} \mathrm{~mol} \mathrm{~m}^{-3}\right)$

$C_{\text {low }}^{\mathrm{Fe}_{2} \mathrm{~B}}$ is the lower limit of the boron content in $\mathrm{Fe}_{2} \mathrm{~B}$

$\left(59.8 \cdot 10^{3} \mathrm{~mol} \mathrm{~m}^{-3}\right)$

$\mathrm{C}_{\text {ads }}^{\mathrm{B}}$ is the adsorbed boron concentration in the boride layer $\left(\mathrm{mol} \mathrm{m}^{-3}\right)$

$a_{1}=C_{\text {up }}^{\mathrm{Fe}_{2} \mathrm{~B}}-C_{\text {low }}^{\mathrm{Fe}_{2} \mathrm{~B}}$ defines the homogeneity range of the $\mathrm{Fe}_{2} \mathrm{~B}$ layer $\left(\mathrm{mol} \mathrm{m}{ }^{-3}\right)$

$a_{2}=C_{\text {low }}^{\mathrm{Fe}_{2} \mathrm{~B}}-C_{0}$ is the miscibility gap $\left(\mathrm{mol} \mathrm{m}^{-3}\right)$

$C_{0}$ is the terminal solubility of the interstitial solute $\left(\approx 0 \mathrm{~mol} \mathrm{~m}^{-3}\right)$

$C_{\mathrm{Fe}_{2} \mathrm{~B}}[x(t)]$ is the boron concentration profile in the $\mathrm{Fe}_{2} \mathrm{~B}$ layer $\left(\mathrm{mol} \mathrm{m}^{-3}\right)$

$v_{0}$ indicates the initial $\mathrm{Fe}_{2} \mathrm{~B}$ layer $(\mathrm{m})$

$\varepsilon$ is the normalized growth parameter for the $\mathrm{Fe}_{2} \mathrm{~B} / \mathrm{sub}-$ strate interface (it has no physical dimensions)

$D_{\mathrm{Fe}_{2} \mathrm{~B}}$ denotes the diffusion coefficient of boron in the $\mathrm{Fe}_{2} \mathrm{~B}$ phase $\left(\mathrm{m}^{2} \mathrm{~s}^{-1}\right)$

$J_{i}[x(t)]$, (with $i=\mathrm{Fe}_{2} \mathrm{~B}$ and $\mathrm{Fe}$ ) are the fluxes of boron atoms at the $\mathrm{Fe}_{2} \mathrm{~B}$ /substrate interface boundary (mol $\left.\mathrm{m}^{-2} \mathrm{~s}^{-1}\right)$ 


\section{Acknowledgements}

The work described in this paper was supported by a grant of CONACyT and PROMEP, México. Also, the authors wish to thank Ing. Martín Ortiz Granillo, the Director of Escuela Superior de Ciudad Sahagún which is part of Universidad Autónoma del Estado de Hidalgo, México, for providing all the facilities necessary to accomplish this research work.

\section{REFERENCES}

${ }^{1}$ A. K. Sinha, Boriding (Boronizing) of Steels, ASM Handbook, vol 4, ASM International, 1991, 437-447

${ }^{2}$ C. Meric, S. Sahin, S. S. Yilmaz, Mater. Res. Bull., 35 (2000) 13, 2165-2172, doi:10.1016/S0025-5408(00)00427-X

${ }^{3}$ H. Okamoto, J. Phase Equilib. Diff., 25 (2004) 3, 297-298, doi:10.1007/s11669-004-0128-3

${ }^{4}$ J. Vipin, G. Sundararajan, Surf. Coat. Technol., 149 (2002), 21-26, doi:10.1016/S0257-8972(01)01385-8

${ }^{5}$ A. Pertek, M. Kulka, Appl. Surf. Sci., 202 (2002), 252-260, doi:10.1016/S0169-4332(02)00940-6

${ }^{6}$ I. Campos, J. Oseguera, U. Figueroa, J. A. Garcia, O. Bautista, G. Keleminis, Mater. Sci. Eng. A, 352 (2003) 1-2, 261-265, doi:10.1016/S0921-5093(02)00910-3

${ }^{7}$ M. Keddam, Appl. Surf. Sci., 236 (2004) 1, 451-455, doi:10.1016/ j.apsusc.2004.05.141

${ }^{8}$ R. D. Ramdan, T. Takaki, Y. Tomita, Mater. Trans., 49 (2008) 11, 2625-2631

${ }^{9}$ D. S. Kukharev, S. P. Fizenko, S. I. Shabunya, J. Eng. Phys. Therm., 69 (1996) 2, 187-193, doi:10.1007/BF02607937

${ }^{10}$ M. Keddam, M. Ortiz-Domínguez, I. Campos-Silva, J. Martinez-Trinídad, Appl. Surf. Sci., 256 (2010) 10, 3128-3132, doi:10.1016/ j.apsusc.2009.11.085

${ }^{11}$ I. Campos-Silva, M. Ortiz-Domínguez, H. Cimenoglu, R. EscobarGalindo, M. Keddam, M. Elías-Espinosa, N. López-Perrusquia, Surf. Eng., 27 (2011) 3, 189-195, doi:10.1179/026708410X12550773057820

${ }^{12}$ M. Ortiz-Domínguez, E. Hernandez-Sanchez, J. Martinez-Trinídad, M. Keddam, I. Campos-Silva, Kovove Mater., 48 (2010) 5, 285-290

${ }^{13}$ I. Campos-Silva, N. López-Perrusquia, M. Ortiz-Domínguez, U. Figueroa-López, O. A. Gómez-Vargas, A. Meneses-Amador, G. Rodríguez-Castro, Kovove Mater., 47 (2009) 2, 75-81

${ }^{14}$ M. Keddam, R. Chegroune, Appl. Surf. Sci., 256 (2010) 16, 5025-5030, doi:10.1016/j.apsusc.2010.03.048
${ }^{15}$ M. Ortiz-Domínguez, M. Keddam, M. Elias-Espinosa, O. DamiánMejía, M. A. Flores-Rentería, A. Arenas-Flores, J. Hernández-Ávila, Surf. Eng., 30 (2014), 490-497, doi:10.1179/1743294414Y. 0000000273

${ }^{16}$ M. Elias-Espinosa, M. Ortiz-Domínguez, M. Keddam, M. A. FloresRentería, O. Damián-Mejía, J. Zuno-Silva, J. Hernández-Ávila, E. Cardoso-Legorreta, A. Arenas-Flores, J. Mater. Eng. Perform., 23 (2014), 2943-2952, doi:10.1007/s11665-014-1052-2

${ }^{17}$ M. Kulka, N. Makuch, A. Pertek, L. Maldzinski, J. Solid State Chem., 199 (2013), 196-203, doi:10.1016/j.jssc.2012.12.029

${ }^{18}$ C. M. Brakman, A. W. J. Gommers, E. J. Mittemeijer, J. Mater. Res., 4 (1989), 1354-1370, doi:10.1557/JMR.1989.1354

${ }^{19}$ L. G. Yu, X. J. Chen, K. A. Khor, G. Sundararajan, Acta Mater., 53 (2005), 2361-2368, doi:10.1016/j.actamat.2005.01.043

${ }^{20}$ V. I. Dybkov, Reaction Diffusion and Solid State Chemical Kinetics, Trans Tech Publications, Switzerland-UK-USA 2010, 7

${ }^{21}$ G. Palombarini, M. Carbucicchio, J. Mater. Sci. Lett., 6 (1987), 415-416, doi:10.1007/BF01756781

${ }^{22}$ I. Campos-Silva, D. Bravo-Bárcenas, A. Meneses-Amador, M. Ortiz-Dominguez, H. Cimenoglu, U. Figueroa-López, J. AndracaAdame, Surf. Coat. Technol., 237 (2013), 402-414, doi:10.1016/ j.surfcoat.2013.06.083

${ }^{23}$ H. Kunst, O. Schaaber, Härterei-Tech. Mitt., 22 (1967), 275

${ }^{24}$ I. Campos-Silva, M. Ortiz-Domínguez, O. Bravo-Bárcenas, M. A. Doñu-Ruiz, D. Bravo-Bárcenas, C. Tapia-Quintero, M. Y. JiménezReyes, Surf. Coat. Technol., 205 (2010), 403-412, doi:10.1016/ j.surfcoat.2010.06.068

${ }^{25}$ I. S. Dukarevich, M. V. Mozharov, A. S. Shigarev, Metallovedenie Termicheskaya i Obrabotka Metallov, 2 (1973), 64-66, doi:10.1007/ BF00679753

${ }^{26}$ S. Sen, U. Sen, C. Bindal, Vacuum, 77 (2005), 195-202, doi:10.1016/j.vacuum.2004.09.005

${ }^{27}$ M. Ulutan, M. M. Yildirim, O. N. Celik, S. Buytoz, Tribol. Lett., 38 (2010), 231-239, doi:10.1007/s11249-010-9597-1

${ }^{28}$ C. Badini, D. Mazza, J. Mater. Sci. Lett., 23 (1988), 661-665

${ }^{29}$ C. Bindal, A. H. Ucisik, Surf. Coat. Technol., 122 (1999), 208-213, doi:10.1016/S0257-8972(99)00294-7

${ }^{30}$ S. Sen, U. Sen, C. Bindal, Surf. Coat. Technol., 191 (2005) 2-3, 274-285, doi:10.1016/j.surfcoat.2004.03.040

${ }^{31}$ O. N. Celik, N. Aydinbeyli, H. Gasan, Prakt. Metallogr., 45 (2008) 7, 334-347, doi:10.3139/147.100390

${ }^{32}$ M. Ipek, G. Celebi Efe, I. Ozbek, S. Zeytin, C. Bindal, J. Mater. Eng. Perform., 21 (2012) 5, 733-738, doi:10.1007/s11665-012-0192-5 